\title{
SCREENING ANTIBACTERIAL EFFECTS OF VIETNAMESE PLANT EXTRACTS AGAINST PATHOGENS CAUSED ACUTE HEPATOPANCREATIC NECROSIS DISEASE IN SHRIMPS
}

\author{
HAI THANH NGUYEN ${ }^{1}$, LUA THI DANG ${ }^{2 *}$, HANH THI NGUYEN ${ }^{2}$, HAI HA HOANG ${ }^{3}$, HA THI NGOC LAI ${ }^{3}$, \\ HA THI THANH NGUYEN ${ }^{4}$
}

${ }^{1}$ Department of Plant Biotechnology, Faculty of Biotechnology, Vietnam National University of Agriculture, Gia Lam, Hanoi, Vietnam. ${ }^{2}$ Center for Environment and Disease Monitoring in Aquaculture, Research Institute for Aquaculture No. 1, Tu Son, Bac Ninh, Vietnam. ${ }^{3}$ Department of Biochemistry andd Food Biotechnology, Faculty of Food Sciences and Technology, Vietnam National University of Agriculture, Gia Lam, Hanoi, Vietnam. ${ }^{4}$ Department of Veterinary Pharmacology and Internal Medicine, Faculty of Veterinary Medicine, Vietnam National University of Agriculture, Gia Lam, Hanoi, Vietnam. Email: danglua@ria1.org

Received: 11 November 2017, Revised and Accepted: 16 January 2018

ABSTRACT

Objectives: The objectives are aimed to investigate the antibacterial properties of five Vietnamese medicinal plants against acute hepatopancreatic necrosis disease (AHPND)-caused bacterial pathogens, to verify their potentials to apply as a new treatment therapy.

Methods: Extracts from plants, such as Psidium guajava leaf, Piper betle L. leaf, Phyllanthus amarus leaf, Rhodomyrtus tomentosa seed, and Allium sativum bulb, were tested against three AHPND-caused bacteria. Agar infusion and broth dilution methods were employed to evaluate extract in vitro antibacterial effects, while experiments with cultured whiteleg shrimps were applied to access their safety when applied in vivo. High-performance liquid chromatography (HPLC) analysis was applied to identify components in the extracts.

Results: P. amanus and R. tomentosa extracts exerted the strongest inhibition on tested bacteria. Other extracts, including P. betel and P. guajava, were less effective, while A. sativum showed no effects against bacteria. In safety assessment experiments, we observed that only crude extracts of $R$. tomentosa and A. satium were safe, while others significantly reduced their survival rates. HPLC showed that extracts of high antibacterial properties had rich phenol constituents. In addition, the phenolic profile of $R$. tomentosa showed the presence of piceatannol.

Conclusion: Considering both of antibacterial effects and safety properties altogether, we concluded that among the five examined plant materials of this study, R. tomentosa had the highest potential to apply in AHPND treatment, as only this plant showed the high effects on pathogenic bacteria while were still safe for host aquatic shrimps.

Keywords: Medicinal plant, Rhodomyrtus tomentosa, Antibacterial effect, Acute hepatopancreatic necrosis disease, Acute hepatopancreatic necrosis disease, Shrimp.

(C) 2018 The Authors. Published by Innovare Academic Sciences Pvt Ltd. This is an open access article under the CC BY license (http://creativecommons. org/licenses/by/4. 0/) DOI: http://dx.doi.org/10.22159/ajpcr.2018.v11i5.23618

\section{INTRODUCTION}

A new lethal disease, termed early mortality syndrome or acute hepatopancreatic necrosis disease (AHPND), has been emerged in Vietnam and caused a severe damage to the country shrimp aquaculture [1,2]. After the outbreak of China in 2009, this disease spreads sequentially to Vietnam (2010), Malaysia (2011), Thailand (2012), and Mexico (2013) [3]. AHPND causes mortality of as high as $100 \%$ [4] and has destroyed up to about $80 \%$ of the shrimp products in some affected areas [5]. In 2013, the causative agent of AHPND was identified as unique isolates of Vibrio parahaemolyticus [1]. In addition, researchers have recently found that virulence genes on plasmid might be transferred not only among $V$. parahaemolyticus strains but also to different bacterial species. These bacteria were identified as Vibro harveyi, isolated from affected shrimps in Vietnam and labeled as Vibro harveyi KC13.17.5 (V. harveyi KC13.17.5) [4]. Therefore, pathogenic bacteria of AHPND outbreaks in Vietnam have been so far identified as not only V. parahaemolyticus but also V. harveyi KC13.17.5. Based on this background, our study decided to test plant effects on AHPND pathogenic bacteria by examining their effects with $V$. parahaemolyticus KC12.020, V. parahaemolyticus KC13.14.2, and V. harveyi KC13.17.5, which had been isolated from AHPND-affected shrimps in Vietnam $[4,6]$.

As microbial disease in aquaculture industries makes serious financial loss, and the antibiotic application in treatment shows many side effects; the search for an alternative method, such as medicinal plants, has been proposed to improve the quality and sustainability of aquaculture production [7-9]. Researchers have observed that medicinal plants not only exert high antimicrobial properties on aquatic bacteria but also have positive effects on the growth and survival rates of aquatic animals, and therefore, proposed their use as a high potential therapy to replace chemotherapeutic molecule use for aquaculture $[7,10]$. In case of the new emerging AHPND of shrimps, several remedies to control the disease have been proposed, but a definite solution remains unclear [11]. In addition, antibiotic resistance has been detected on AHPND pathogenic bacterial strains, including those were isolated from the affected shrimps in Vietnam [11], suggesting that investigation on other treatment methods, such as the use of medicinal plants, would be useful in the search for an effective solution.

In this present study, we tested antibacterial effects of five Vietnamese medicinal plants, such as Psidium guajava leaf, Piper betle L. leaf, Phyllanthus amarus leaf, Rhodomyrtus tomentosa seed, and Allium sativum bulb, against the three pathogenic AHPND bacterial strains isolated in Vietnam, to evaluate their therapeutic potentials. In addition, we also characterized the compounds in plants and performed feeding experiments with shrimps to assess their in vivo safety. In our study, we decided to choose the five plants because Vietnamese ethnic medicine had described them as therapies for diseases associated by bacterial infections $[12,13]$, and they had shown high effects on other aquatic bacteria in our previous results [14-16]. 


\section{METHODS}

\section{Source of AHPND-caused bacterial pathogens}

Virulent bacterial strains such as V. parahaemolyticus KC12.020, V. parahaemolyticus KC13.14.2, and V. harveyi $\mathrm{KC} 13.17 .5$ used in this study were isolated from AHPND-affected shrimps during this disease outbreak in Vietnam. Their biochemical, virulent, and molecular analysis had been previously performed [4,17]. After being glycerol stocked, these bacteria were preserved at $-80^{\circ} \mathrm{C}$ and kept in our laboratory, Department of Aquatic Animal Diseases, Research Institute for Aquaculture No. I, Vietnam.

\section{Confirmation of AHPND-caused bacteria by polymerase chain reaction (PCR)}

To confirm AHPND-caused bacterial strains at genomic level, DNAs were extracted from the bacterial strains which grown on nutrient broth growth medium and used as DNA templates for the PCR analysis employing AP3 primers (Forward: 5Forward: rs NA templates for ow and reverse: 5 versed: rs NA templates forand toxin gene primers (forward: 5rw GTGGAAATGGTGAACTTGCG-3' and reverse: $5^{\prime}$ - TACGAGCATTGTTAGGGGTTA-3'), provided from laboratory of Genome Science, Tokyo University of Marine Science and Technology. PCR conditions were performed for 30 cycles and as follows: An initial denaturation at $94^{\circ} \mathrm{C}$ for $5 \mathrm{~min}$ and each cycle with denaturation at $94^{\circ} \mathrm{C}$ for $30 \mathrm{~s}$, annealing at $53^{\circ} \mathrm{C}$ for $30 \mathrm{~s}$, extension at $72^{\circ} \mathrm{C}$ for $40 \mathrm{~s}$, and final extension at $72^{\circ} \mathrm{C}$ for $5 \mathrm{~m}$. PCR amplified products were resolved in a $1 \%$ agarose gel containing ethidium bromide by electrophoresis and visualized under UV light. The positive results showed a band with a size of 336 bp for AP3 primers [18] and a size of $630 \mathrm{bp}$ for toxin primers.

\section{Plant materials and extraction}

Five plants, including P. guajava, $P$. betle, $P$. amarus, $R$. tomentosa, and A. sativum, were collected from Vietnam. Their identities were confirmed by Dr. Tho Thi Bui based on voucher specimens that had been deposited at Vuon Duoc Lieu Thu Y Herbarium, Vietnam National University of Agriculture in Vietnam. After collecting, the plant materials were washed, preliminarily shade-dried before further dried at $50^{\circ} \mathrm{C}$ for $15 \mathrm{~h}$. They were then ground individually into powders with a particle size $<0.1 \mathrm{~mm}$, put in airtight plastic bags kept in dried cool chambers. Samples were tested within 6 months from the preparation time. P. guajava, P. betle, $P$. amarus, and A. sativum were extracted by $70 \%$ ethanol with $1 / 10$ ratio of plant powder/ethanol. Followed Lai et al. [19] recommendation, $R$. tomentosa was extracted by ethanol $79 \%$ with $1 / 20$ ratio of plant powder/ethanol. Solutions were centrifuged at $6,000 \mathrm{rpm}$ for $10 \mathrm{~m}$ at $4^{\circ} \mathrm{C}$. The supernatants were concentrated by a rotatory evaporator at $40^{\circ} \mathrm{C}$, and extracts were dried with a lyophilizer before being stored at $4^{\circ} \mathrm{C}$ until use [19].

\section{Preparation of bacterial concentration}

Three bacterial strains, V. parahaemolyticus KC12.020, $V$. parahaemolyticus $\mathrm{KC13.14.2,} \mathrm{and} \mathrm{V.} \mathrm{harveyi} \mathrm{KC} 13.17 .5$, were taken from glycerol stocks at $-80^{\circ} \mathrm{C}$ and streaked on the thiosulfate citrate bile salt plates and incubated at $29^{\circ} \mathrm{C}$ for $24 \mathrm{~h}$. After that, a single colony of each strain was selected and cultured individually in $50 \mathrm{ml}$ nutrient broth supplemented with $2 \%$ of $\mathrm{NaCl}$ and incubated at $29^{\circ} \mathrm{C}$ for $15 \mathrm{~h}$ in a shaking incubator (shaking speed: $200 \mathrm{rpm}$ ). The concentrations of bacteria were calculated based on optical density (OD) values obtained with a spectrophotometer at the wavelength of $\lambda=600 \mathrm{~nm}$. The bacterial concentrations were adjusted to $10^{8} \mathrm{CFU} / \mathrm{ml}$ in the test with plant extracts.

\section{Investigation of antibacterial effects against AHPND-caused vibrio bacterial strains}

Evaluation of antibacterial effects with agar disc diffusion method

Antibacterial effects were determined through measuring the inhibitory zones induced by the extracts. In brief, plant extracts were dissolved in dimethyl sulfoxide (DMSO) to make concentrations of $10 \mu \mathrm{g} / \mu \mathrm{l}$,
$15 \mu \mathrm{g} / \mu \mathrm{l}, 20 \mu \mathrm{g} / \mu \mathrm{l}, 25 \mu \mathrm{g} / \mu \mathrm{l}$, and $30 \mu \mathrm{g} / \mu \mathrm{l}$ and examined with bacteria, followed the agar disc diffusion method of Bauer et al. [20]. The extract disc contained $100 \mu \mathrm{l}$ of extract, while the positive control disc contained doxycycline $(30 \mu \mathrm{g})$ or ampicillin $(10 \mu \mathrm{g})$ and the negative control disc contained only $100 \mu \mathrm{l}$ DMSO. The discs were placed on Mueller Hinton agar plates and incubated at $29^{\circ} \mathrm{C}$ for $24 \mathrm{~h}$. Diameters of inhibitory zones induced by the extracts were interpreted as follows: Resistant (12 mm or less), intermediate (13-15 mm), and susceptible (16 $\mathrm{mm}$ or more), followed the standard that has been used to evaluate effects of plants on bacteria [14].

\section{Evaluation of antibacterial effects by broth dilution method}

Antibacterial effects were determined through the determination of minimum inhibitory concentration (MIC) and minimum bactericidal concentration (MBC) values of the plant extracts. In brief, extracts were initially dissolved in DMSO to make the stock solutions and then diluted into the nutrient broth to make the two-fold diluted concentrations that ranged from $19 \mu \mathrm{g} / \mathrm{ml}$ to $5000 \mu \mathrm{g} / \mathrm{ml}$ to test with bacteria. MIC values were determined as the lowest concentration that completely inhibited the growth of bacteria after $24 \mathrm{~h}$ of incubation at $29^{\circ} \mathrm{C}$, and MBC values were determined as the lowest concentrations that inhibited the bacterial growth after they were plated again on nutrient agar and further incubated for $24 \mathrm{~h}$.

\section{High-performance liquid chromatography (HPLC) analysis of plant extracts}

The method used for HPLC of extracts was modified from Lai et al. [21]. After being filtered through $0.45 \mu \mathrm{m}$ pore-size syringe (Phenex ${ }^{\mathrm{TM}}$-NY, Utrecht, The Netherlands), $20 \mu \mathrm{L}$ of extract was analyzed using a 150 $\times 4.6 \mathrm{~mm}$ i.d.; Kinetex $5 \mu \mathrm{m}$ C18 column equipped with a guard column of the same type (Phenomenex, Netherlands). The mobile phases were: (A) $\mathrm{H}_{2} \mathrm{O}$ with $0.1 \%$ formic acid, and (B) acetonitrile with $0.1 \%$ formic acid. The gradient conditions were as follows: $0-5 \mathrm{~min}, 0-15 \% \mathrm{~B}$; 5-20 min, $15-20 \%$ B; $20-30 \mathrm{~min}, 20-100 \%$ B; $30-35 \mathrm{~min}, 100 \%$ B; 35-40 $\mathrm{min}, 100-0 \% \mathrm{~B}$; and $40-42 \mathrm{~min}, 0 \% \mathrm{~B}$. Other chromatographic conditions were as follows: Flow rate: $0.3 \mathrm{ml} / \mathrm{min}$, column temperature: $30^{\circ} \mathrm{C}$, and run time: $42 \mathrm{~min}$. The identification of compounds in extracts was followed by the study of Robards et al. [22].

\section{Safety assessment of plant extracts \\ Preparation of whiteleg shrimp}

Whiteleg shrimp (weigh of 2-3 g) bought from a shrimp farm in Nghe An Province was stocked in a seawater aquaria to assess their diseasefree health status for 7 days. We divided the healthy shrimps into six experimental groups ( $\mathrm{n}=90$ per group, except for the control group in which $\mathrm{n}=30$ ), and each group housed in three subgroups of nine glass tanks (n=10 per tank and 3 tanks for sub-group) containing $50 \mathrm{~L}$ of artificial seawater and equipped with an air supply system. Each subgroup was nominated for each tested concentration of plant extract, and three tanks for subgroup indicated the triplication. The shrimps were maintained under the following conditions: $26-28^{\circ} \mathrm{C}, \mathrm{pH}=7.5-$ 8.5 , DO $\geq 4 \mathrm{mg} / \mathrm{L}$, and $25 \mathrm{ppt}$.

\section{Preparation of feed pellets coated with plant extracts}

Five tested plant powders were separately mixed with distilled water, sprayed onto shrimp feed pellets, and mixed before coating with cod liver oil (Merck). Mixing ratio of plant extract powders and pellets was optimized so that concentrations of each plant extracts were $50 \mathrm{mg} / \mathrm{g}$ pellet, $75 \mathrm{mg} / \mathrm{g}$ pellet, and $100 \mathrm{mg} / \mathrm{g}$ pellet. The ratio of cod liver oil to pellets was $2 \mathrm{ml} / 100 \mathrm{~g}$. Those feed pellets were stocked for maximum $15 \mathrm{~d}$ at $4^{\circ} \mathrm{C}$ until use.

\section{Safety assessment of plant extracts on whiteleg shrimps}

Pellets without or with plant extracts were used to feed shrimps at the amounts equivalent to $1-2 \%$ of shrimp body weights. For each plant material, nine tanks of shrimps were used for extract-coated pellets at three different concentrations, and three tanks were used for control. 
All experiments were performed in triplication, and survival rates were recorded every day, in the period of 14 days.

\section{Statistical analysis}

Data were expressed as mean \pm standard error (mean \pm SEM). One-way ANOVA followed by post hoc Bonferroni test was used to compare the inhibitory zones induced by different extract concentrations and the survival rates of different groups in safety assessment test. Two-factor ANOVA followed by post hoc Bonferroni test was used to compare the inhibitory zones induced by different extracts. In all analysis, significance was established when probability level was equal to or $<5 \%(\mathrm{p}<0.05)$.

\section{RESULTS}

PCR analysis of AHPND-caused bacterial strains

Applying AP3 detection method and toxin primer for AHPND using PCR analysis, we confirmed that three strains, including $V$. parahaemolyticus KC12.020, V. parahaemolyticus KC13.14.2, and V. parahaemolyticus sp. KC13.17.5, are the pathogenic bacteria that cause AHPND in shrimps (Fig. 1a and b). PCR results of those bacteria showed bands that were the same as that of the positive control DNA at $336 \mathrm{bp}$ when using AP3 primers (Fig. 1a) and at 630 bp when using toxin primer (Fig. 1b)

\section{Antibacterial effects of plant extracts against AHPND-caused} Vibrio bacterial strains

Inhibitory zones ( $\mathrm{mm}$ of diameter) induced by five plant extracts against three AHPND-caused bacterial strains are shown in Table 1. We observed that while P. guajava, P. betle, P. amanus, and R. tomentosa exerted inhibitory effects at various levels, depending on bacterial strains and concentrations, while A. sativum showed no effects, as it induced no inhibitory zones at all tested concentrations. In addition, the inhibition of P. guajava, P. betle, P. amanus, and R. tomentosa was dosedependent, because following the increment in applied concentrations, there were also significantly increments in their induced inhibitory zones (Table 1). Among 5 tested plants, the effects of $P$. amanus and $R$. tomentosa were remarkable, because their extracts always induced the inhibitory zones that represented bacterial susceptibility $(>16 \mathrm{~mm})$ for all 3 tested strains, while others, such as P. guajava and P. betle, induced such kind of inhibitory zones for only one or two bacteria, respectively. The results were further evident with Fig. 2, which compares the inhibitory zones induced by the four extracts and shows that regardless of tested concentrations, $P$. amanus and $R$. tomentosa always represented the highest antibacterial effects, as shown by their significantly larger inhibitory zones (Fig. 2). The determination of MIC and MBC by a broth dilution method, as shown in Table 1, also further confirmed the high effects of $P$. amanus and $R$. tomentosa, as regardless of bacterial strains, the two extracts' MIC and MBC values were always lower than those of others, such as P. guajava and P. betle (Table 1). The results thus demonstrated their stronger effects in both of inhibitory and bactericidal activities (Table 2)

Chromatographic, spectral characterization and identification of main compounds in potential plant extracts

The summary of peaks in chromate profiles of extracts from five plants is shown in Table 3. According to Table 3, major peaks in profiles of four extracts of high antibacterial effects, including $P$. guajava, P. amanus, $P$. betle, and R. tomentosa (As shown in Table 1. Inhibitory zone (mm) induced by plant extracts against AHPND-caused bacterial strains) were mainly identified as phenolic compounds. Based on previous results on phenolic constituents of $R$. tomentosa [19,21], peaks of $R$. tomentosa extract profile in our study were further identified as hydrolysable tannins (including Di-HHDP-galloyl-glucose, HHDP-galloyl-glucose, HHDP-digalloyl-glucose, furosin, and HHDP-trigalloyl-glucose) and stilbenes (including astringin, piceatannol, and resveratrol). In chromate profile of A. sativum, we observed that there were two minor peaks represented phenol compounds, while all other peaks, including the major ones, showed the retention times that are different from phenols and remained unknown in this study, due to the lack of our laboratory authentic standards (Table 3 ).

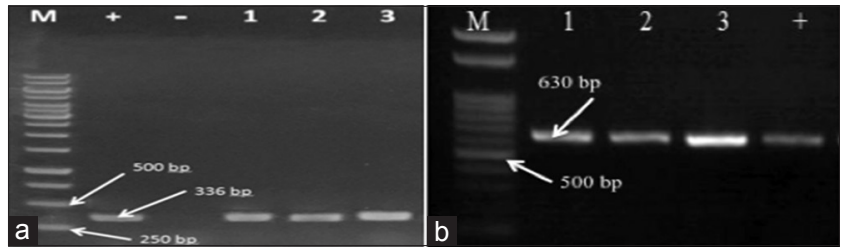

Fig. 1: Confirmation of acute hepatopancreatic necrosis diseasecaused bacterial strains by PCR analysis (a) using AP3 primer and

(b) using toxin primer. (1) Vibrio parahaemolyticus KC12.020,

(2) V. parahaemolyticus KC13.14.2, (3) V. parahaemolyticus sp. KC13.17.5, (4) distilled water, (+) positive (control) DNA template and $(\mathrm{M})$ marker $100 \mathrm{bp}$

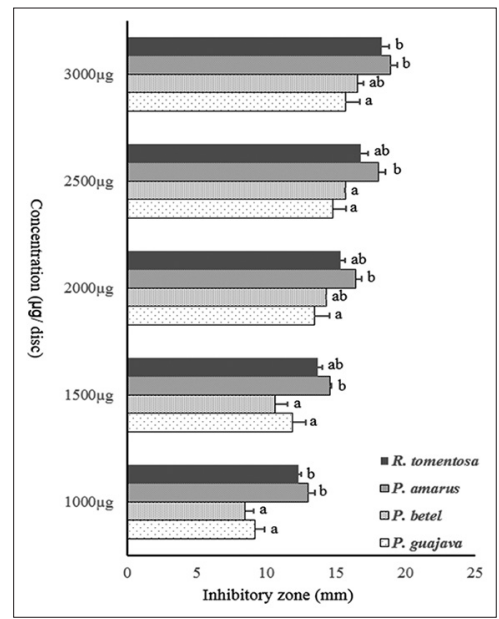

Fig. 2: Means of inhibitory zones of extracts from different plant materials to three acute hepatopancreatic necrosis diseasecaused bacterial strains. Each value was mean of inhibitory zones of each extract at each concentration of three bacteria. Values with different superscripts in each concentration are significantly different $(p<0.05)$ by two-factor ANOVA followed by Bonferroni post hoc analysis

\section{Safety assessment of plant extracts}

The safety assessment results of plant extracts on cultured whiteleg shrimps are shown in Fig. 3. The survival rates of shrimps fed with R. tomentosa and A. sativum at concentrations of $50 \mathrm{mg} / \mathrm{g}$ and $75 \mathrm{mg} / \mathrm{g}$ remained $100 \%$ in all experimental period (14 d), while those of shrimp fed with $P$. guajava, $P$. amarus, and $P$. betle were significantly decreased in all tested concentrations. These results indicated that only extracts from R. tomentosa and A. sativum, at the concentrations of $<100 \mathrm{mg} / \mathrm{g}$, were safe to be directly applied in the shrimp feeding.

\section{DISCUSSION}

There has been a number of studies reported antibacterial effects of medicinal plants on V. parahaemolyticus and V. harveyi [7,23-29], but our study represents the second attempt to investigate plant effects on AHPND pathogenic bacteria, followed one report in 2014 [30]. In addition, it is the first time that plants were tested against the AHPND pathogenic bacterium that was different from V. parahaemolyticus and was closet to $V$. harveyi and the $V$. harveyi KC13.17.5 strain. We observed that four of five examined plants, including P. guajava, P. amanus, P. betel, and R. tomentosa, showed antibacterial activities at different levels. These results were similar to previous studies that reported these plants' effects on bacteria [31-37] and further give evidence to explain their Vietnamese ethnic applications in bacterial diseases $[12,13]$. In addition, our results demonstrated that among all tested plants, P. amanus and $R$. tomentosa had outstanding effects on AHPND-caused bacteria, as they always represented the strongest activities, regardless of applied investigation methods (agar disc diffusion or broth dilution) and also regardless of tested strains (V. parahaemolyticus 


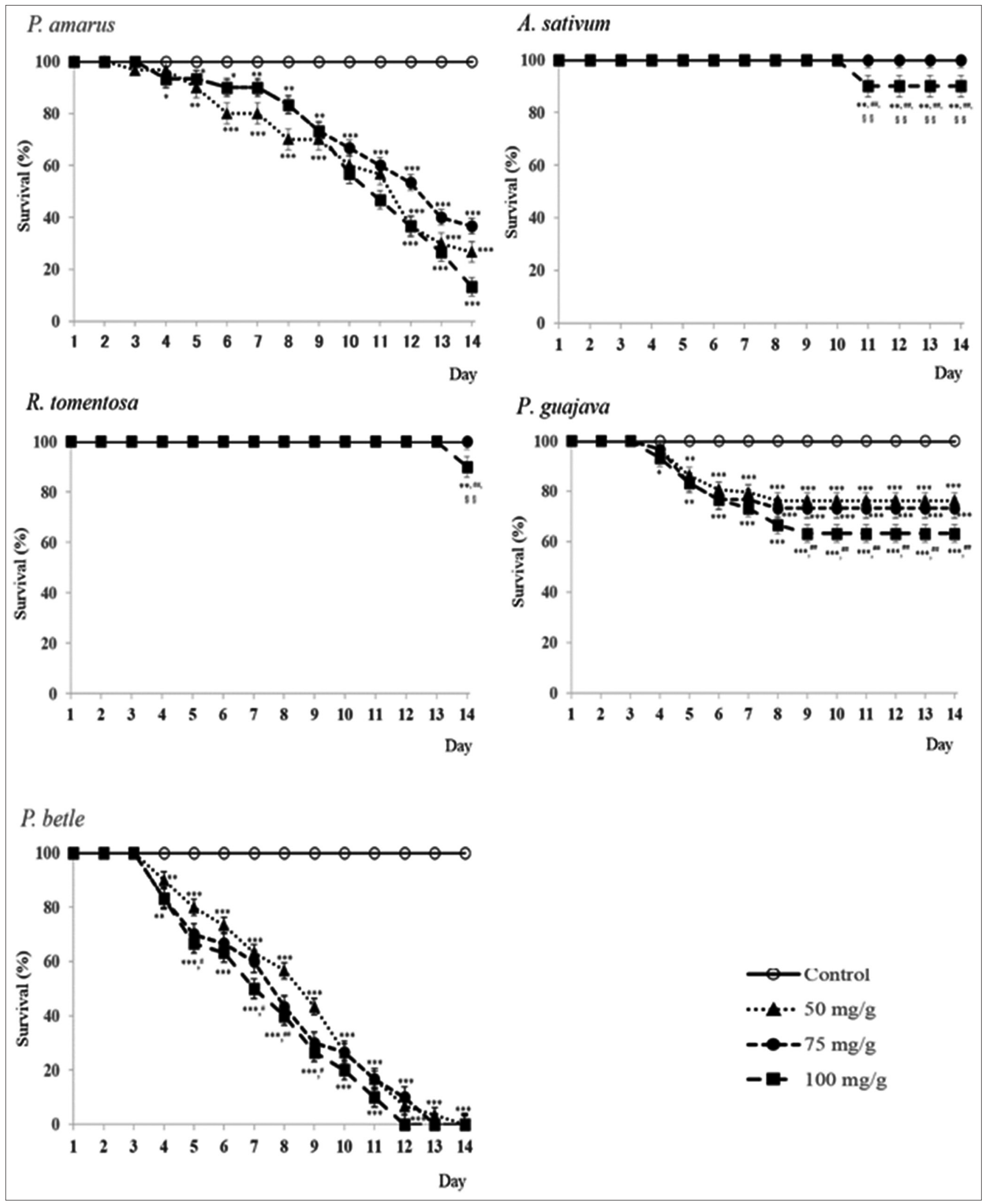

Fig. 3: Survival rates of cultured whiteleg shrimps fed without extract ( $O e$ and with extract at different concentrations (ct (75 mg/g extrace, $75 \mathrm{mg} / \mathrm{g}$ pellet, and $\mathrm{m}, 100 \mathrm{mg} / \mathrm{g}$ pellet). Each point represents the mean \pm SEM for three experiments. The values of different groups were compared by one-way ANOVA followed with Bonferroni post hoc analysis $\left({ }^{*} \mathrm{p}<0.05 \mathrm{vs}\right.$. control, ${ }^{* *} \mathrm{p}<0.01 \mathrm{vs}$. control, ${ }^{* * *}$ p $<0.001$ vs. control, ${ }^{\#}$ p $<0.05$ vs. $50 \mathrm{mg} / \mathrm{g}$ pellet, ${ }^{\# \#}$ p $<0.01$ vs. $50 \mathrm{mg} / \mathrm{g}$ pellet, $\$ \mathrm{p}<0.05 \mathrm{vs.} 75 \mathrm{mg} / \mathrm{g}$ pellet, and $\$ \$ \mathrm{p}<0.01 \mathrm{vs.} 75 \mathrm{mg} / \mathrm{g}$ pellet) by two-factor ANOVA followed by Bonferroni post hoc analysis 
Table 1: Inhibitory zone ( $\mathrm{mm})$ induced by plant extracts against AHPND-caused bacterial strains

\begin{tabular}{|c|c|c|c|c|}
\hline \multirow[t]{2}{*}{ Plant extract } & \multirow[t]{2}{*}{ Concentration $(\mu \mathrm{g} / \mathrm{disc})$} & \multicolumn{3}{|l|}{ Bacterial strains } \\
\hline & & V. parahaemolyticus $\mathrm{KC12.020}$ & V. parahaemolyticus KC13.14.2 & V. harveyi KC13.17.5 \\
\hline \multirow[t]{5}{*}{ P. guajava } & 1000 & $10.3^{\mathrm{a}} \pm 1.2$ & $9.3^{\mathrm{a}} \pm 3.2$ & $8.0^{\mathrm{ab}} \pm 1.7$ \\
\hline & 1500 & $13.7^{b} \pm 0.6$ & $11.3^{\mathrm{bc}} \pm 3.1$ & $10.7^{b} \pm 0.6$ \\
\hline & 2000 & $15.7^{\mathrm{cd}} \pm 0.6$ & $12.3^{\mathrm{cd}} \pm 2.3$ & $12.3^{\mathrm{cd}} \pm 0.6$ \\
\hline & 2500 & $16.7^{\mathrm{de}} \pm 1.5$ & $14.0^{\mathrm{de}} \pm 1.7$ & $13.7^{\mathrm{de}} \pm 1.2$ \\
\hline & 3000 & $17.7^{\mathrm{e}} \pm 0.6$ & $14.7^{\mathrm{e}} \pm 2.5$ & $14.7^{\mathrm{e}} \pm 1.5$ \\
\hline \multirow[t]{5}{*}{ P. betel L. } & 1000 & $9.7^{\mathrm{a}} \pm 0.6$ & $7.7^{\mathrm{a}} \pm 1.5$ & $8.0^{\mathrm{ab}} \pm 1.0$ \\
\hline & 1500 & $11.7^{\mathrm{b}} \pm 0.6$ & $11.3^{\mathrm{b}} \pm 1.5$ & $9.0^{\mathrm{b}} \pm 1.0$ \\
\hline & 2000 & $14.3^{\mathrm{cd}} \pm 1.2$ & $14.3^{\mathrm{cd}} \pm 1.2$ & $14.3^{\mathrm{cd}} \pm 1.2$ \\
\hline & 2500 & $15.7^{\mathrm{de}} \pm 0.6$ & $15.7^{\mathrm{de}} \pm 1.2$ & $15.7^{\mathrm{d}} \pm 1.2$ \\
\hline & 3000 & $15.7^{\mathrm{e}} \pm 0.6$ & $17.0^{\mathrm{e}} \pm 1.0$ & $17.0^{\mathrm{e}} \pm 1.0$ \\
\hline \multirow[t]{5}{*}{ P. amarus } & 1000 & $12.0^{\mathrm{a} \pm} 1.0$ & $13.3^{\mathrm{ab}} \pm 1.5$ & $13.7^{\mathrm{ab}} \pm 0.6$ \\
\hline & 1500 & $14.3^{\mathrm{b}} \pm 0.6$ & $14.7^{\mathrm{b}} \pm 1.2$ & $14.7^{\mathrm{b}} \pm 0.6$ \\
\hline & 2000 & $16.0^{c} \pm 1.0$ & $17.3^{\mathrm{cd}} \pm 0.6$ & $16.0^{\mathrm{cd}} \pm 1.0$ \\
\hline & 2500 & $18.0^{\mathrm{de}} \pm 2.0$ & $19.0^{\mathrm{de}} \pm 1.0$ & $17.3^{\mathrm{d}} \pm 2.1$ \\
\hline & 3000 & $18.0^{\mathrm{e}} \pm 1.0$ & $19.7^{\mathrm{e}} \pm 0.6$ & $19.0^{\mathrm{e}} \pm 1.7$ \\
\hline \multirow{4}{*}{ R. tomentosa } & 1500 & $13.0^{\mathrm{b}} \pm 2.0$ & $13.7^{b c} \pm 1.5$ & $14.3^{\mathrm{bc}} \pm 1.2$ \\
\hline & 2000 & $15.7^{c} \pm 1.2$ & $14.7^{\mathrm{cd}} \pm 0.6$ & $15.7^{\mathrm{cd}} \pm 2.3$ \\
\hline & 2500 & $17.3^{\mathrm{de}} \pm 0.6$ & $15.7^{\mathrm{d}} \pm 1.5$ & $17.3^{\mathrm{d}} \pm 1.2$ \\
\hline & 3000 & $18.0^{\mathrm{e}} \pm 0.3$ & $17.7^{\mathrm{e}} \pm 0.6$ & $19.3^{\mathrm{e}} \pm 0.6$ \\
\hline \multirow[t]{5}{*}{ A. sativum } & 1000 & 0 & 0 & 0 \\
\hline & 1500 & 0 & 0 & 0 \\
\hline & 2000 & 0 & 0 & 0 \\
\hline & 2500 & 0 & 0 & 0 \\
\hline & 3000 & 0 & 0 & 0 \\
\hline DMSO & & 0 & 0 & 0 \\
\hline Am $(10 \mu \mathrm{g})$ & & 0 & 0 & 0 \\
\hline Dox $(30 \mu \mathrm{g})$ & & $23.0 \pm 2.2$ & $22.9 \pm 1.8$ & $23.3 \pm 2.4$ \\
\hline
\end{tabular}

Amp: Ampicillin, Dox: Doxycycline. Each value represents the mean \pm SEM for three experiments. Numbers with different superscripts (a-e) are significantly different by one-way ANOVA followed with Bonferroni test $(\mathrm{p}<0.05)$. Bold letters indicate the zone diameters that are interpreted as susceptibility $(\geq 16 \mathrm{~mm})[14]$, P. guajava: Psidium guajava, P. betel: Piper betel, P. amarus: Phyllanthus amarus, R. tomentosa: Rhodomyrtus tomentosa, A. sativum: Allium sativum, DMSO: Dimethyl sulfoxide, AHPND: Acute hepatopancreatic necrosis disease, V. parahaemolyticus: Vibrio parahaemolyticus

Table 2: MIC and MBC of plant extracts on AHPND-caused bacterial strains

\begin{tabular}{lll}
\hline Plant extract & Bacterial strains & \\
\cline { 2 - 3 } & V. parahaemolyticus KC12.020 & V. parahaemolyticus KC13.14.2 \\
\hline MIC & 625 & 625 \\
P. guajava & 625 & 625 \\
P. betel L. & 312 & 312 \\
P. amarus & 312 & 312 \\
R. tomentosa & 1250 & \\
MBC & 1250 & 1250 \\
P. guajava & 625 & 1250 \\
P. betel L. & 625 & 625 \\
P. amarus & & 625 \\
R. tomentosa & & 156 \\
\hline
\end{tabular}

MIC: Minimum inhibitory concentration, MBC: Minimum bacterial concentration, AHPND: Acute hepatopancreatic necrosis disease, V. parahaemolyticus: Vibrio parahaemolyticus, P. guajava: Psidium guajava, P. betel: Piper betel, P. amarus: Phyllanthus amarus, R. tomentosa: Rhodomyrtus tomentosa, A. sativum: Allium sativum

KC12.020, V. parahaemolyticus KC13.14.2, or V. harveyi KC13.17.5). The in vivo experiments on cultured shrimps showed that only two extracts, including $R$. tomentosa and A. sativum, were safe when applying in feeding, while others significantly affected the survival rates. By combining these safety assessment results and those of antibacterial effects, we concluded that $R$. tomentosa had the highest therapeutic potentials for the treatment of shrimp AHPND, as only this plant yielded the high effects on pathogenic bacteria but was still relatively safe for host aquatic animals. HPLC analysis showed the significant constituents of polyphenols in extracts that had antibacterial activities, suggesting that phenols might be responsible, at least in part, for their effects with bacteria. Detailed identification of phenol constituents in $R$. tomentosa showed the presence of compounds that had been known to have antibacterial properties, such as hydrolyzable tannins [38], resveratrol [39], and piceatannol [40-42]. In addition, because piceatannol is the main phenolic compound of $R$. tomentosa [21] and its strong effects have been well established on bacteria, including the pathogenic strains of aquaculture [40-42], it is likely to speculate the significant role of this compound in $R$. tomentosa strong effects with AHPND-caused bacteria observed in the current study. However, we have not yet isolated and examined piceatannol from $R$. tomentosa on these bacteria, and the roles and mechanisms of piceatannol are still remained to identify in future researches.

Even $R$. tomentosa has a long history of application in ethnic medicine $[12,13,19,43]$, its biological and pharmacological properties have not yet been well established, and it is listed as one of 240 "Neglected and Underutilised Crop Sciences" of Vietnam, China, Thailand, and Cambodia by the scientific project "Agrofolio" [44]. The current study highlights $R$. tomentosa antibacterial effects and safety, recommends it as a promissory candidate to treat AHPND of shrimps, 
Table 3: The identification of compounds in plant extracts by HPLC analysis

\begin{tabular}{|c|c|c|c|}
\hline Plant extract & Retention time (min) & Absorbance maxima (nm) & Assigned group/compound \\
\hline \multirow[t]{7}{*}{ R. tomentosa } & 8.55 & 272 & DiHHDP-galloyl-glucose \\
\hline & 8.78 & 270 & HHDP-galloyl-glucose \\
\hline & 9.08 & 275 & HHDP-digalloyl-glucose \\
\hline & 9.61 & 275 & Furosin \\
\hline & 9.91 & 301 & Astringin \\
\hline & 11.31 & 277 & HHDP-trigalloyl-glucose \\
\hline & 13.86 & 324 & Piceatannol \\
\hline \multirow[t]{8}{*}{ P. guajava } & 8.29 & 274 & Phenolic acid, flavanol, or tannin \\
\hline & 8.50 & 270 & Phenolic acid, flavanol, or tannin \\
\hline & 8.76 & 267 & Phenolic acid, flavanol, or tannin \\
\hline & 9.24 & 273 & Phenolic acid, flavanol, or tannin \\
\hline & 12.47 & 253,363 & Flavonol \\
\hline & 12.97 & 256,354 & Flavonol \\
\hline & 13.36 & 263,354 & Flavonol \\
\hline & 14.98 & 255,354 & Flavonol \\
\hline P. betle $\mathrm{L}$ & 27.44 & 279 & Phenolic acid, flavanol, or tannin \\
\hline P. amanus & 9.58 & 273 & Phenolic acid, flavanol, or tannin \\
\hline \multirow[t]{6}{*}{ A. sativum } & 1.63 & 255 & Unknown \\
\hline & 2.25 & 273 & Phenolic acid, flavanol, or tannin \\
\hline & 3.30 & 247 & Unknown \\
\hline & 5.00 & $266,279,286$ & Unknown \\
\hline & 12.40 & 244 & Unknown \\
\hline & 14.10 & 277 & Unknown \\
\hline
\end{tabular}

V. parahaemolyticus: Vibrio parahaemolyticus, P. guajava: Psidium guajava, P. betel: Piper betel, P. amarus: Phyllanthus amarus, R. tomentosa: Rhodomyrtus tomentosa, A. sativum: Allium sativum, HPLC: High-performance liquid chromatography

and thus suggests that more research attentions would be justified to verify the therapeutic potential of this plant. In addition, further studies investigating the effects of $R$. tomentosa on shrimps in AHPND pathological conditions are still necessary to access the plant in vivo treatment properties, and therefore, they will be performed by the followed up research of our current project (NAFOSTED, number 106NN.05-2013.48).

\section{CONCLUSION}

This study investigated the effects of five medicinal plant extracts on AHPND pathogenic bacterial strains, to evaluate their treatment potentials. The results showed that $P$. amanus and $R$. tomentosa had the strongest antibacterial activities, followed by P. guajava and P. betle, while $A$. sativum had no effects. On the other hand, safety assessment experiments showed that only $R$. tomentosa and $A$. sativum were safe in the feeding application. By considering the two results altogether, our study highlighted $R$. tomentosa as the medicinal plant of the highest therapeutic potential for AHPND in shrimps, because it had strong effects on pathogenic bacteria while was safe for the host animals, and therefore, this plant will be further verified in the follow-up researches of our project.

\section{ACKNOWLEDGMENTS}

The authors express sincere thanks to Dr. Ikuo Hirono, Head of Laboratory of Genome Science, Tokyo University of Marine Science and Technology, for providing us the positive DNA template of AHPND and the primers for amplifying AHPND toxin genes. We also thank to Dr. Tho Thi Bui for the identification of plant materials. This research was funded by Vietnam National Foundation for Science and Technology Development (NAFOSTED) under the grant number 106-NN.05-2013.48.

\section{COMPETING INTERESTS}

All authors declare that they have no competing interests.

\section{AUTHORS' CONTRIBUTIONS}

The work presented here was carried out in the collaboration between all authors. The two first authors, Lua Thi Dang and Hai Thanh Nguyen, were the main investigators of the study. Other authors, including Hanh Thi Nguyen, Hai Ha Hoang, Ha Thi Ngoc Lai, and Ha Thi Thanh Nguyen participated in the collection, preparation, and extraction of medicinal plants and assisted the first two authors in the HPLC analysis and in vivo experiments. Lua Thi Dang revised the final form of this manuscript and is the corresponding author.

\section{REFERENCES}

1. Tran L, Nunan L, Redman RM, Mohney LL, Pantoja CR, Fitzsimmons K, et al. Determination of the infectious nature of the agent of acute hepatopancreatic necrosis syndrome affecting penaeid shrimp. Dis Aquat Organ 2013;105:45-55.

2. Flegel TW. Historic emergence, impact and current status of shrimp pathogens in Asia. Invertebr Pathol 2012;110:166-73.

3. Thitamadee S, Prachumwat A, Srisala J, Jaroenlak P, Salachan PV, Sritunyalucksana $\mathrm{K}$, et al. Review of current disease threats for cultivated penaeid shrimp in Asia. Aquaculture 2016;452:69-87.

4. Kondo H, Van PT, Dang LT, Hirono I. Draft genome sequence of Non-vibrio parahaemolyticus acute hepatopancreatic necrosis disease

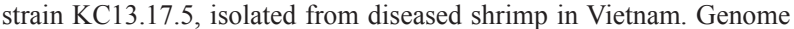
Announc 2015;3:e00978-15.

5. Zorriehzahra MJ, Banaederakhshan R. Early mortality syndrome (EMS) as new emerging threat in shrimp industry. Adv Anim Vet Sci 2015;3:64-72

6. Dang LT, Nguyen KV, Pham VT. Non-vibrio parahaemolyticus gay benh hoai tu gan tuy cap (AHPND) tren tom nuoi. Vietnam J Agric Sci 2016;14:690-8.

7. Immanuel G, Vincybai VC, Sivaram V, Palavesam A, Marian MP. Effect of butanolic extracts from terrestrial herbs and seaweeds on the survival, growth and pathogen (Vibrio parahaemolyticus) load on shrimp Penaeus indicus juveniles. Aquaculture 2005;236:53-65.

8. Li J, Tan B, Mai K, Ai Q, Zhang W, Xu W, et al. Comparative study between probiotic bacterium Arthrobacter XE-7 and chloramphenicol on protection of Penaeus chinensis post-larvae from pathogenic vibrios. Aquaculture 2006;253:140-7.

9. Ngo VH. The use of medicinal plants as immunostimulants in aquaculture: A review. Aquaculture 2015;446:88-96.

10. Kirubakaran CJ, Alexander CP, Michael RD. Enhancement of nonspecific immune responses and disease resistance on oral administration of Nyctanthes arbortristis seed extract in Oreochromis mossambicus (Peters). Aquac Res 2010;41:1630-9. 
11. Han JE, Mohney LL, Tang KF, Pantoja CR, Lightner DV. Plasmid mediated tetracycline resistance of Vibrio parahaemolyticus associated with acute hepatopancreatic necrosis disease (AHPND) in shrimps. Aquac Rep 2015;2:17-21.

12. Do, T.L. Nhung cay thuoc va vi thuoc thuong dung tai Vietnam. [Book in Vietnamese]. $13^{\text {rd }}$ ed. Hanoi, Vietnam: Vietnam Medical Publishing House; 2005. p. 97-435. (a): Cay oi. Psidium guajava. In: Do, T.L. (Eds.), pp. 431-432. (b): Cho de rang cua. Phyllanthus amarus. In: Do, T.L. (Eds.), Hanoi, Vietnam: Vietnam Medical Publishing House; 2005. p. 97-98. (c): Trau khong. Piper betel L. In: Do, T.L. (Eds.), Hanoi, Vietnam: Vietnam Medical Publishing House; 2005. p. 118-119. (d): Sim. Rhodomyrtus tometosa Wight. In: Do, T.L. (Eds.), Hanoi, Vietnam: Vietnam Medical Publishing House; 2005. p. 434-435. (e): Toi. Allium sativum L. In: Do, T.L. (Eds.), Hanoi, Vietnam: Vietnam Medical Publishing House; 2005. p. 181-182.

13. Le, V.T. and Nguyen, G.C. Selected Medicinal plants in Vietnam. ${ }^{\text {st }}$ ed., Vol. I, II. Hanoi, Vietnam: Vietnam National Institute of Materia Medica Publications, Science and Technology Publishing House; 1999. (a): Piper betle L. - Piperaceae. In: Le, V.T. and Nguyen, G.C. (Eds.), $1^{\text {st }}$ ed., Vol. II. Hanoi, Vietnam: Vietnam National Institute of Materia Medica Publications. Science and Technology Publishing House; 1999. p. 179-182. (b): Pluchea indica (L.) Less. Asteraceae. In: Le, V.T. and Nguyen, G.C. (Eds.), $1^{\text {st }}$ ed., Vol. II. Hanoi, Vietnam: Vietnam National Institute of Materia Medica Publications. Science and Technology Publishing House; 1999. p. 189-192. (c): Rhodomyrtus tomentosa (Ait.) Hassk. - Myrtaceae. In: Le, V.T. and Nguyen, G.C. (Eds.), $1^{\text {st }}$ ed., Vol. II. Hanoi, Vietnam: Vietnam National Institute of Materia Medica Publications. Science and Technology Publishing House; 1999. p. 241-243.

14. Bui TT, editor. Tac Dung Khang Khuan Cua Thao Duoc: Phytoantibacterial effects. [Document in Vietnamese]. Phuong Phap Nghien Cuu cay Thuoc-Tai Lieu Tham Khao Cho Nghien Cuu Sinh va hoc Vien cao hoc lam de tai Nghien cuu ve cay Thuoc (luu hanh noi bo trong phong thi nghiem). Hanoi, Vietnam: Department of Internal Medicine and Pharmacology, Faculty of Veterinary Medicine, Vietnam National University of Agriculture; 2012. p. 18-9.

15. Dang TL, editor. Ket qua nghien cuu tac dung cua mot so cay thuoc voi vi khuan gay benh thuy san. [Document in Vietnamese]. Phuong Phap Nghien Cuu Thao Duoc Voi Benh Thuy san (Luu Hanh Noi Bo Trong Phong Thi Nghiem). Tu Son, Bac Ninh, Vietnam: Center for Environment and Disease Monitoring in Aquaculture, Research Institute for Aquaculture No. 1; 2012. p. 8-21

16. Bui TT, Nguyen TH. Tap Hop Cac Ket Qua Nghien Cuu Ve Tac Dung Cua Thuc Vat Voi Vi Khuan Thu y [Document in Vietnamese]. In: Nguyen TH, editros. Tap Hop Cac Ket Qua Nghien Cuu Khoa Hoc Ve Cay Thuoc Cua Sinh Vien Dai Hoc (Luu Hanh Noi Bo Trong Phong Thi Nghiem Duoc Ly Thu Y). Gia Lam, Hanoi, Viet Nam: Laboratory of Veterinary pharmacology, Vietnam National University of Agriculture; 2010. p. 38-40.

17. Phan VT, Dang LT, Nguyen KV, Bui TN, Pham VT, Pham YT, et al. Nghien cuu xac dinh nguyen nhan gay benh hoai tu gan tuy cap tren tom tai phia Bac. Bao cao tong ket de tai cap Bo. (Studies on the cause of AHPND in shrimp cultured in Northern Vietnam. Final National project report) (In Vietnamese language). 2014.

18. Sirikharin R, Taengchaiyaphum S, Sritunyalucksana K, Thitamadee S, Flegel TW, Mavichak R, et al. New and Improved PCR Method for Detection of AHPND Bacteria. Available from: http://www.enaca.org/ modules/news/article.php?article id $=230 \&$ title $=$ new-pcr- detectionmethod-for-ahpnd 2014. [Last cited on 2014 Jun 18].

19. Lai TN, Andre CM, Chirinos R, Nguyen TB, Larondelle Y, Rogez H. Optimisation of extraction of piceatannol from Rhodomyrtus tomentosa seeds using response surface methodology. Sep Purif Technol 2014;134:139-46.

20. Bauer AW, Kirby WM, Sherris JC, Truck M. Antibiotic susceptibility testing by a standardized single disc method. Am J Clin Pathol 1966;45:493-96

21. Lai TN, Herent MF, Quetin-Leclercq J, Nguyen TB, Rogez H, Larondelle $\mathrm{Y}$, et al. Piceatannol, a potent bioactive stilbene, as major phenolic component in Rhodomyrtus tomentosa. Food Chem 2013; 138:1421-30

22. Robards K, Prenzler PD, Tucker G, Swatsitang P, Glover, W. Phenolic compounds and their role in oxidative processes in fruits. Food Chem 1999;66:401-36

23. Asha S, Anitha S, Anantharajan R. Antibacterial activity of herbal plant extracts towards the fish pathogens. Internet J Microbiol 2007;4:1-5.
24. Direkbusarakom S. Application of medicinal herbs to aquaculture in Asia. Walailak J Sci Tech 2004;1:7-14

25. Pirbalouti G, Hamedi B, Malek Poor F, Rahimi E, Nasri Nejhad R. Inhibitory activity of Iranian endemic medicinal plants against Vibrio parahaemolyticus and Vibrio harveyi. J Med Plants Res 2011;5:7049-53.

26. Sankar G, Ramamoorthy K, Sakkaravarthi K, Elavarsi A. Antibacterial activity of herbal extract on pathogens isolated from the swollen hind gut of P. Monodon (Fabricus). Pharm Sin 2010;1:17-22.

27. Sivaram V, Babu MM, Immanuel G, Murugadass S, Citarasu T, Marian MP. Growth and immune response of juvenile greasy groupers (Epinephelus tauvina) fed with herbal antibacterial active principle supplemented diets against Vibrio harveyi infections. Aquaculture 2004:237:9-20

28. Velmurugan S, Punitha SM, Babu MM, Selvaraj T, Citarasu T. Indian herbal medications to replace antibiotics for shrimp Penaeus monodon post larvae. J Appl Aquacult 2010;22:230-9.

29. Velmurugan S, Viji VT, Babu MM, Punitha MJ, Citarasu T. Antimicrobial effect of Calotropis procera active principles against aquatic microbial pathogens isolated from shrimp and fishes. Asian Pacific J Trop Biomed 2012;2:S812-7.

30. Kua BC, Ahmad IA, Siti-Zahrah A, Nik HN, Fadzilah Y, Irence J. Effectiveness of Betel Leave (Piper betle) and Lemongrass (Cympopogon citratus) Extracts on Challenged Whiteleg shrimp, Litopenaeus vannamei with Vibrio parahaemolyticus that Caused AHPND. Ho Chi Minh City, Vietnam: Poster Presented at $9^{\text {th }}$ Symposium on Diseases in Asian Aquaculture; 2014. p. 91.

31. Dhandapani R, Lakshmi D, Balakrishnan V, Jayakumar S, Kumar A. Preliminary phytochemical investigation and antibacterial activity of Phyllanthus amarus Schum \& Thorn. Anc Sci Life 2007;27:1-5.

32. Limsuwan S, Kayser O, Voravuthikunchai SP. Antibacterial activity of Rhodomyrtus tomentosa (Aiton) hassk. Leaf extract against clinical isolates of Streptococcus pyogenes. Evid Based Complement Alternat Med 2012;2012:697183.

33. Morais-Braga MF, Carneiro JN, Machado AJ, Dos Santos AT, Sales DL, Lima LF, et al. Psidium guajava L., from ethnobiology to scientific evaluation: Elucidating bioactivity against pathogenic microorganisms. J Ethnopharmacol 2016;194:1140-52

34. Valle DL Jr, Cabrera EC, Puzon JJ, Rivera WL. Antimicrobial activities of methanol, ethanol and supercritical $\mathrm{CO} 2$ extracts of Philippine Piper betle $\mathrm{L}$. On clinical isolates of gram positive and gram negative bacteria with transferable multiple drug resistance. PLoS One 2016;11:e0146349.

35. Deshpande SN, Kadam DG. GCMS analysis and antibacterial activity of Piper betle (Linn) leaves against Streptococcus mutans. Asian J Pharm Clin Res 2013;6:99-101.

36. Hussain RM, Ho FK, Mustakim M, Suhaimi H. Upregulation of TRXB expression by Piper betel Linn ethanolic extract suggests induction of oxidative stress which potentially contributes to killing of Staphylococcus aureus in vitro. Int J Pharm Pharm Sci 2015;7:154-9.

37. Jayalakshmia B, Raveeshab KA, Muralic M, Amruthesh KN. Phytochemical, antibacterial and antioxidant studies on leaf extracts of Piper betle L. Int J Pharm Pharm Sci 2015;7:23-9.

38. Buzzini P, Arapitsas P, Goretti M, Branda E, Turchetti B, Pinelli P, et al. Antimicrobial and antiviral activity of hydrolysable tannins. Mini Rev Med Chem 2008;8:1179-87.

39. Paulo L, Ferreira S, Gallardo E, Queiroz JA, Domingues F, Antimicrobial activity and effects of resveratrol on human pathogenic bacteria. World J Microbiol Biotechnol 2010;26:1533-8

40. Piotrowska H, Kucinska M, Murias M. Biological activity of piceatannol: Leaving the shadow of resveratrol. Mutat Res 2012;750:60-82.

41. Plumed-Ferrer C, Väkeväinen K, Komulainen H, Rautiainen M, Smeds A, Raitanen JE, et al. The antimicrobial effects of woodassociated polyphenols on food pathogens and spoilage organisms. Int J Food Microbiol 2013;164:99-107

42. Schrader KK. Plant natural compounds with antibacterial activity towards common pathogens of pond-cultured channel catfish (Ictalurus punctatus). Toxins (Basel) 2010;2:1676-89.

43. Hamid HA, Mutazah SS, Yusoff MM. Rhodomyrtus tomentosa: A phytochemical and pharmacological review. Asian J Pharm Clin Res 2017; $10: 10-6$.

44. Agro Forestry Tree Database. Tree Species Reference and Selection Guide: Rhodomyrtustomentosa. Available from: http:// www.worldagroforestrycentre.org/sea/Products/AFDbases/af/asp/ SpeciesInfo.asp?SpID=18093. [Last accessed on 2011 Sep 24]. 